\title{
From the margins to the mainstream: towards a history of published Indigenous Australian autobiographies and biographies
}

\section{Oliver Haag}

Published Indigenous Australian autobiographies have undergone considerable change over the last five decades. ${ }^{1}$ From tentative beginnings between the $1950 \mathrm{~s}$ and the 1970s, they saw tremendous growth during the 1980s and 1990s. Now, 50 years later, autobiographies have secured their place in overseas markets. This article reconstructs some aspects of this development. ${ }^{2}$ More precisely, I first present an extended bibliography and then make a statistical profile to contextualise the statistical findings within a broader historical frame. 'Extended bibliography' is understood to incorporate several variables relevant to the statistical survey, including year of first publication, genre, gender, publisher, and production-authorship. ${ }^{3}$

\section{Compiling a bibliography}

Any bibliography must rely on a consistent definition of its sources. In this instance, two ideas require a definition: 'what makes an autobiography an autobiography?' and 'what makes it Indigenous?' The latter idea in particular should be comparable to self-perceptions: 'how do Indigenous authors define their own work?' Anita Heiss elaborates on this question in her seminal analysis Dhuuluu-Yala. ${ }^{4}$ Following her findings, my principle is that a work must at least be co-authored by an Indigenous person to be identified as Indigenous. ${ }^{5}$ Other indicators, such as subject-matter and perspective, are too imprecise to use in constructing a definition and they tend to homogenise what is, more often than not, highly diverse. This definition thus excludes all biographies about Indigenous persons, as well as authors such as Mudrooroo, whose indigeneity is contested. ${ }^{6}$

This definition, however, is complicated by early autobiographies that do not meet the criterion of shared authorships, such as, for example, Hetherington's Aboriginal queen of sacred song, Thonemann's Tell the white man, or Lockwood's $I$, the Aboriginal. ${ }^{7}$ Including them as Indigenous autobiographies is a matter of perspective because the issue of actual authorship was relatively unimportant in these earlier works. I have excluded them from this analysis because their 
contexts of production and reception are too different from those that I wish to study.

Compared to authorship, genre is a more complex topic. Scholarly literature has applied more than 10 different genres to Indigenous autobiography: autobiography, autobiographical narrative, life history, life story, life writing, testimony, history, Indigenous history, oral history, auto-ethnography, and novel. ${ }^{8}$ Most of these genres closely relate to each other because they revolve around life experiences. Their differences, however, can be both subtle and substantial. While some stress the oral background of Indigenous autobiography, others heed the differences in the historical depth of a narrated life, stretching from aspects of a life to an entire life cycle. Further genres gauge a clear distinction between self-productions and 'as-told-to' stories. ${ }^{9}$ Yet, it is striking that, while (or exactly because) the autobiography is ranked as one of the most widely used genres, it is also one of the most fiercely criticised. While Rowse, Brewster, and Watson deploy the term autobiography, a considerable number of other researchers use other terms such as life history. ${ }^{10}$ Interestingly, this is not the case with the term biography. Moreton-Robinson, for example, prefers life writing and life 'herstories' to autobiography, considering that the Indigenous autobiographical self was not in any sense individualistic but relational, communal, and connected to others through spirituality and/or place. ${ }^{11}$ Westphalen holds that the term autobiography has tended to conceal the actual origin of Indigenous life histories, namely, the discourses of the Dreamings. ${ }^{12}$ In turn, Mudrooroo decried the autobiography as an individualistic and apolitical 'battler genre'. 13

Conventional literary definitions of autobiography play a major role in this critique, referring in particular to the understanding that the autobiography presupposes a completely individualised self. ${ }^{14}$ From such a perspective, Indigenous autobiographies are indeed fundamentally different. They rest upon a distinctively oral background as well as a wealth of inter-generational story-telling networks. Their presentation is often dialogic rather than purely retrospective, taking the form of direct speech. They are often communal instead of entirely individual. All of this, however, does not mean that the term autobiography as such is unhelpful. For example, (Indigenous) feminist theorists have criticised and expanded the narrow focus on individualism. ${ }^{15}$ To me, then, the term autobiography is not necessarily a misnomer for Indigenous life narratives because it finally depends on how the genre itself is defined. Bearing this in mind, I adopt the following working definition: both autobiography and biography can at least be identified as distinct genres of Indigenous literature. While the autobiography is a life-narrative principally narrated by the protagonist(s), the biography is a life-narrative principally narrated about the protagonist(s). 
In my bibliography, I do not distinguish between individualised and relational selves, dialogic and descriptive styles, or collaborative and independent works. Nor is it important whether a publication covers an entire life circle or focuses upon select aspects of a life. Furthermore, this bibliography includes published books and excludes manuscripts, journal articles, reports, and ethnographic field studies. I do not consider such forms to be equivalent to books, at least as far as public reception and marketing are concerned. The 'Bulman Oral History Series' are a special case. Although they are added to a separate rubric in the bibliography, they are not part of the sample underlying the statistics. ${ }^{16}$ All items included are authored or co-authored by an Indigenous person; authorship follows gender so that men's autobiographies have to be authored by men. Indigenous autobiographies are sometimes a composition of different life stories of different protagonists. In this respect, they bear some similarities to related genres like family or community history. Nevertheless, such genres are different from autobiographies and thus excluded from the bibliography. This bibliography also does not include semi-autobiographies or autobiographical novels. In many cases, this bibliography draws upon the National Library of Australia Cataloguing-in-Publication Data. It also takes into account similar bibliographies, such as those compiled by Heiss, Watson, and Schürmann-Zeggel. ${ }^{17}$ Lastly, no bibliography of Indigenous autobiographies should ever be considered definitive.

\section{Retracing the history of Indigenous autobiographies}

My goal, then, is to provide an overview. For this purpose, I explored approximately 400 books across different genres, published between 1950 and 2004, before selecting 177 which qualified as published autobiographies for analysis.

I make three general observations relating to authorship, genre, and increase: ${ }^{18}$

(1) Authorship: The overall ratio between female and male authors is 3 to 2, meaning that women have authored around 60 per cent of the 177 books issued between 1950 and 2004. There are signs that this numerical imbalance corresponds to a broader pattern of Indigenous literature: in the survey To tell my story, around 66 per cent of Indigenous writers are female. ${ }^{19}$ Most of the autobiographies (98 per cent) were published in the period of self-determination (from the late 1960s onwards). ${ }^{20}$ Males prevailed by 55 per cent during the first phase, prior to 1988, while women dominated by 64 per cent during the second period. The Indigenous autobiography, it seems, has become a female-dominated genre. David Unaipon (1951) is the first male Indigenous autobiographer, and Theresa Clements (c 1954) is the first female.

(2) Genre: The bulk of Indigenous life writing is autobiographical (81 per cent). A more recent phenomenon, biographies did not gain a foothold until the 
mid-1980s. In all, 38 per cent of Indigenous autobiographies are co-authored ('as-told-to' stories). Statistically, both these genres do not show any gender-based differentials. This means that, in contrast to the autobiography, the biography is neither a more male nor female genre and that co-authoring is not specifically gendered. Only anthologies (collections of several distinct contributors) are dominated by female authors (71 per cent).

(3) Increase: Measuring by decade-specific data, the number of publications has continuously increased since the 1960s. That is, the 1970s saw, in nominal terms, more publications than the 1960s, the 1980s saw more than the 1970s, and the 1990s saw more than the 1980s. The number in the 2000s will likely surpass the 1990s. While 6.8 books were published a year on average during the 1990s, 15.2 books were published a year during the period of 2000 to 2004. This steady increase also applies to co-productions and biographies.

In the case of co-authoring and production processes, these changes have been not only quantitative but also qualitative. As scholars such as Jones and McDonell have explored, there are now substantial discourses on how to collaborate, edit, and publish Indigenous autobiographies. ${ }^{21}$ This, along with the establishment of Indigenous publishers, has led many publishing houses to maintain Indigenous English and idiomatic styles of expression. Also, while many autobiographies were exclusively transcribed and edited by non-Indigenous persons, they are now increasingly co-produced by Indigenous persons, including My place, When the pelican laughed, or Auntie Rita. ${ }^{22}$ Together, these factors suggest a consistent progression of the Indigenous autobiography, due to the consistent increase in publishing in general and the numbers for co-productions and biographies in particular. The history of Indigenous autobiography has indeed followed a linear path of progression.

This history has, however, also been distinguished by uneven developments. I have ascertained two different phases in the evolvement of Indigenous autobiography: from 1951 to 1987 (20 per cent of all items) and from 1988 to 2004. This corresponds with the findings of other scholars such as Brewster and Olijnyk Longley, who also consider the late 1980 s as a turning point. ${ }^{23}$ There may be at least three reasons for this: publications have increased enormously, the 'publishing landscape' has changed, and Indigenous autobiographies have started to acquire an international reputation.

\section{(1) The Increase in Publications}

In spite of the fact that published Indigenous autobiographies date from 1951, rapid expansion did not begin until the late 1980s, after when their growth was dramatic. But, unlike the decade-specific pattern, year-to-year data reveal an uneven growth rate characterised by four major peaks in publications (see Figure 1.1). The first of these occurred in 1977 and 1978, after the first Whitlam reforms, 
such as the implementation of the (new) Australia Council, had taken effect. The second major peak occurred in the two years following the Bicentenary in 1988. The third occurred in 1995 between the Mabo judgment and the tabling of the Bringing them home Report. The final peak was in the year of the Sydney Olympic Games, 2000.

Ratio of Female to Male Autobiographers - Year Specific (1969-2004)

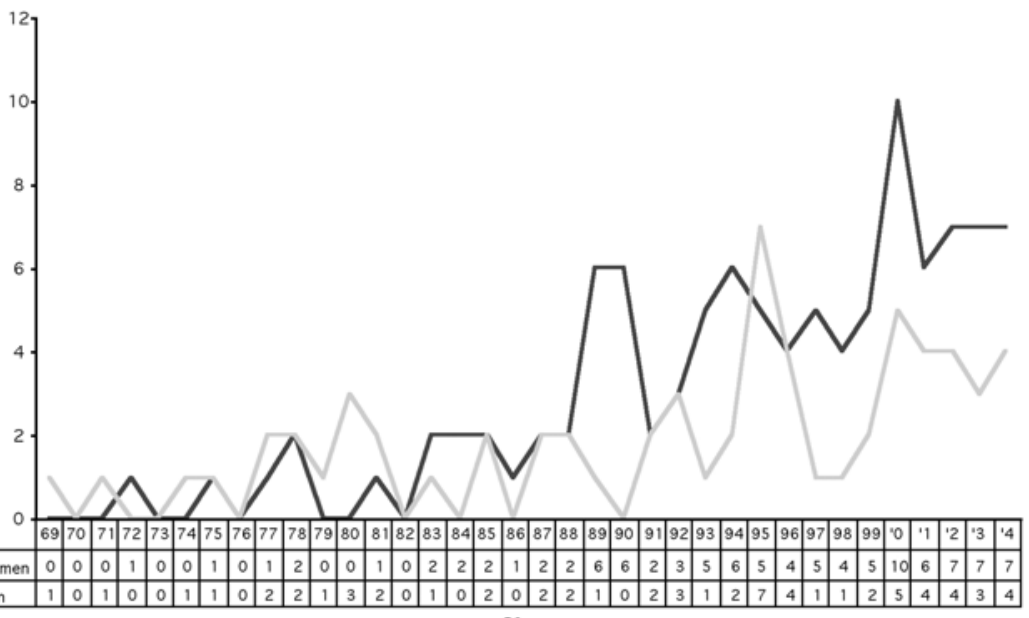

Year

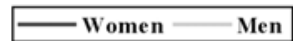

Figure 1.1: Diagram representing both graphically and numerically the number of male and female Indigenous autobiographies published per year. The lower two rows of the figure display the numerical data and form a ratio.

This evidence points to a likely correlation between periods of heightened socio-political activity and the rise in publications. Shoemaker has also identified such a nexus, ${ }^{24}$ and, indeed, the first wave of published Indigenous autobiographies appeared just at the threshold of what is now often perceived as creative period of change - the late 1960s. Political minorities, including Indigenous Australians, became (not least because of the then nation-wide political activisms) increasingly vocal and, therefore, a subject of intense interest. Some 10 years later, the (anti-)celebrations of 200 years of settlement or invasion in 1988 generated a similar demand for Indigenous stories which publishers were eager to meet. ${ }^{25}$ Market demands, in other words, were not steady. Indigenous Australians had become increasingly visible. Audiences and writers followed the trend. 


\section{(2) Changes within the national market}

The proliferation of Indigenous autobiographies has been closely intertwined with the nature of the publishers. In general, most items have been issued by either local presses or through self-publication, both of which have affected their reception. Significantly, none of the autobiographies that are part of the canon in inter/national scholarship has been published in either of these categories of press. Setting this aside, the publishing infrastructure surrounding Indigenous autobiography can be subdivided into Indigenous and mainstream publishers.

The most prolific publishers of Indigenous autobiographies are the two Indigenous presses, Magabala Books and Aboriginal Studies Press (ASP). The former was inaugurated in 1987, the latter in the 1960s. Though not Indigenous, the University of Queensland Press (UQP) - within the scope of its 1990-launched Black Writers Series - ranks third. ${ }^{26}$

As for the mainstream field, four eminent publishing companies, including imprints, stand out: Fremantle Arts Centre Press (FACP), Allen \& Unwin, Angus \& Robertson, and Penguin. Together, they make up 20 per cent of the 177 published Indigenous autobiographies (see Figure 1.2).

\section{Publishers}

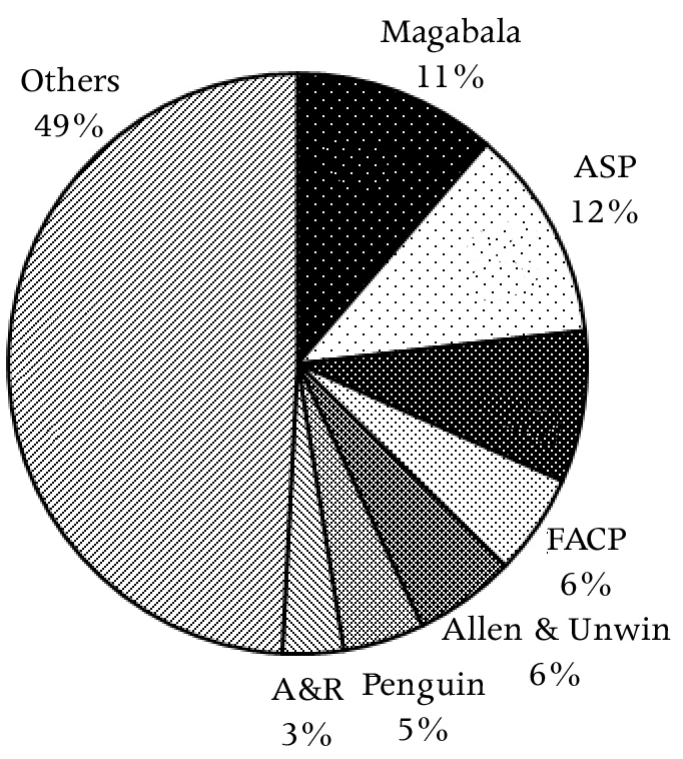

Figure 1.2: Pie chart displaying the relative proportions of the 177 published Indigenous autobiographies each publisher produced. 
Interestingly, Australian feminist presses have not played a significant role. Except for Spinifex Press, none of the major feminist presses, such as Sybylla Press, Women's Redress Press, or Artemis Publishing, has issued Indigenous autobiographies. Other presses evidently also supported women's autobiographies, but a possible correlation between the different gender ratios and a corresponding publishing policy demonstrated by these presses reveals a rather hazy picture: the different ratios in the publications of Magabala Books, ASP, and Penguin are too minuscule to draw any serious conclusion. In contrast, while FACP, Allen \& Unwin, and UQP published significantly more female than male authors, Angus \& Robertson in turn published twice as many male authors. Mainstream and Indigenous publishers have both produced Indigenous autobiographies. This has not always been true, as the publishing landscape has changed drastically since the late 1980s. Firstly, Magabala Books and, shortly thereafter, the UQP Black Writers Series were established. This new infrastructure led to a proliferation of Indigenous autobiographies and culturally sensitive publishing. Secondly, by the late 1980s, Indigenous autobiographies increasingly attracted the attention of the mainstream publishing industry, presumably triggered by the success of My place. ${ }^{27}$ Whatever the different causes, two significant events occurred in the late 1980s: Magabala Books was founded, and Indigenous autobiographies entered a mainstream market and, thus, a new phase.

\section{(3) The entry into an international market}

When the 1980s, especially the Bicentenary, drew to a close, publications of Indigenous autobiographies became increasingly prolific. Since then they have flourished not only within Australia but overseas. Little, however, is known about this international reception and distribution.

International distribution can be analysed from two perspectives: reception, including both readership and scholarship, and the publication, including the translation. Both have seen an enormous expansion within the last two decades. In particular, increasing interest can be observed within the academic field. Indigenous autobiographies have become an intense subject of academic study, demonstrated by an increasing number of university theses. At Austrian universities alone, at least six have been written since 1998. Moreover, Rühl, Schürmann-Zeggel, Zierott, and Duthil have published their studies on Indigenous autobiographies. ${ }^{28}$ These monographs, however, have received only minor attention within Australia.

Indigenous autobiographies have also been taken on by overseas presses. The UK edition of My place was published by Virago Press, a leading publisher of women's literature. The German translation, entitled Ich hörte den Vogel rufen, was published by the feminist press Orlanda Frauenverlag. ${ }^{29}$ The German version of Morgan's Wanamurraganya was released by the mainstream Swiss company 
Unionsverlag. ${ }^{30}$ The Finnish edition of Langford Ginibi's Don't take your love to town, Bonalbon Musta Ruby, was published by Kääntöpiiri, a Christian press. ${ }^{31}$ Long walk home, the German translation of Follow the rabbit-proof fence, was issued by mainstream publisher Rowohlt. ${ }^{32}$ It appears that, in overseas contexts, it is primarily mainstream and feminist presses that have published Indigenous autobiographies. The existence of such a strong commitment on the side of feminist publishing is in stark contrast to the situation in the Australian market. This contrast in part suggests why predominantly, if not exclusively, women authors have been published overseas.

Lastly, I would like to present a note on the complexity of translating Indigenous autobiographies. Translations are an unmistakable sign of success, but also pose a string of critical questions: How is it possible to properly consult with Indigenous authors once a text is rendered into an unfamiliar language? How can a distinctive speech pattern - like dialogic utterance - be maintained in a foreign language? For instance, My place was rendered into a very rough version of Northern German, which sounds extremely artificial to most German speakers. To mention yet another difficulty, the German equivalent of race, Rasse, denotes a purely biological conception of race. Meanwhile, Rasse has become an indubitably racist word that is either substituted for ethnicity (Ethnizität) or avoided completely. Ethnicity, however, does not correspond with current discourses on race and racisms in Australia. How, then, does one translate this word?

\section{Conclusion}

Published Indigenous autobiographies span five decades, during which they have undergone some drastic changes. They have changed from 'male' to 'female', from 'local' to 'global', and from the 'margins' to the 'mainstream'. Particularly since the Bicentenary, they have seen several decisive increases in publication. As I have argued, the late 1980s indeed marks a watershed in the history of published Indigenous autobiography, separating two different phases from one another, and it is in the second phase that they have became an internationally recognised phenomenon. 
Table 1: Extended Bibliography (1951-2004)

\begin{tabular}{|c|c|c|c|}
\hline Author & Year & Author & Year \\
\hline Unaipon/M & 1951 & Cohen ${ }^{*} \mathbf{F}$ & 1990 \\
\hline Clements/F & 1954 & Morgan ${ }^{*} \mathbf{F}$ & 1990a \\
\hline Rose* M & 1969 & Morgan ${ }^{*} \mathbf{F}$ & $1990 b$ \\
\hline Roughsey/M & 1971 & Morgan ${ }^{*} \mathbf{F} / \underline{B}$ & 1990c \\
\hline Noonuccal/F & 1972 & Pring/F & 1990 \\
\hline Lamilami ${ }^{*} \mathbf{M}$ & 1974 & Woodrow/F & 1990 \\
\hline Cawley/F & 1975 & Davis/M & 1991 \\
\hline Perkins/M & 1975 & McGinness/M & 1991 \\
\hline Tatz/M\&F & 1975 & Pilkington/F & 1991 \\
\hline Barker* $\mathbf{M}$ & 1977 & Ward/F & 1991 \\
\hline Jangala/M & 1977 & Dodd/M & 1992 \\
\hline Tucker*F & 1977 & Edmund/F & 1992 \\
\hline Clare/F & 1978 & Langford/F & 1992 \\
\hline McKenna* $\mathbf{M}$ & 1978 & Nannup *F & 1992 \\
\hline Mirritji* $\mathbf{M}$ & 1978 & Saunders/M & 1992 \\
\hline Simon/F & 1978 & Sing ${ }^{*} \mathbf{M}$ & 1992 \\
\hline Dhoulagarle/M & 1979 & Chryssides/F/ $\underline{\mathbf{B}}$ & 1993 \\
\hline Bropho/M & 1980 & Crawford ${ }^{*} \mathbf{F}$ & 1993 \\
\hline Pepper/M/ B & 1980 & Goolagong/F/ $\underline{B}$ & 1993 \\
\hline Raggett *M & 1980 & Lester/M & 1993 \\
\hline MumShirl ${ }^{*} \mathbf{F}$ & 1981 & Prior/F/ $\underline{B}$ & 1993 \\
\hline Ngabidj* $\mathbf{M}$ & 1981 & Sykes/F & 1993 \\
\hline Thaiday/M & 1981 & Anderson/F/ $\underline{\mathbf{B}}$ & 1994 \\
\hline McKenzie/F & $1983 a$ & Harrison/M & 1994 \\
\hline McKenzie/F & $1983 b$ & Huggins/F/ $\underline{B}$ & 1994 \\
\hline Sullivan* $\mathbf{M}$ & 1983 & Langford/F & 1994 \\
\hline Roughsey*F & 1984 & McPhee ${ }^{*} \mathbf{M}$ & 1994 \\
\hline West/F & 1984 & Morgan/F & 1994 \\
\hline Kennedy/F & 1985 & Somerville/F & 1994 \\
\hline Neidjie ${ }^{*} \mathbf{M}$ & 1985 & van den Berg/F/ $\underline{\mathbf{B}}$ & 1994 \\
\hline Rosser/M/ $\underline{\text { B }}$ & 1985 & Bohemia* M & 1995 \\
\hline White/F & 1985 & Camfoo* $\mathrm{F}$ & 1995 \\
\hline $\mathrm{Coe} / \mathbf{F} / \underline{\mathrm{B}}$ & 1986 & Camfoo*M & 1995 \\
\hline Cohen/M & 1987 & Gibbs/M & 1995 \\
\hline Morgan/F & 1987 & Marika* M & 1995 \\
\hline Ward/F & 1987 & McAdam * $\mathbf{M}$ & 1995 \\
\hline Willmot/M/ $\underline{\mathbf{B}}$ & 1987 & Medcraft/F & 1995 \\
\hline Chesson/M/ $\underline{\mathbf{B}}$ & 1988 & Moran/M/ $\underline{\mathbf{B}}$ & 1995 \\
\hline Langford/F & 1988 & Nungurrayi ${ }^{*} F$ & 1995 \\
\hline Lowah/M & 1988 & Pedersen ${ }^{*} \mathbf{M}$ & 1995 \\
\hline Thancoupie *F & 1988 & Vaarzon-Morel ${ }^{*} \mathbf{F}$ & 1995 \\
\hline Gaffney/F & 1989 & Wood/F/ $\underline{\text { B }}$ & 1995 \\
\hline Hamilton ${ }^{*} \mathbf{F}$ & 1989 & Edmund/F/ $\underline{\mathbf{B}}$ & 1996 \\
\hline McKenzie ${ }^{*} \mathbf{F}$ & 1989 & Harney* $\mathbf{M}$ & 1996 \\
\hline Morgan/F/ $\underline{B}$ & 1989 & King/M & 1996 \\
\hline Thomson *F & 1989 & Lennon* $\mathbf{F}$ & 1996 \\
\hline Walker ${ }^{*} \mathbf{F}$ & 1989 & Mabo* M/ $\underline{B}$ & 1996 \\
\hline Wilson/M/ $\underline{\mathbf{B}}$ & 1989 & McDonald *F & 1996 \\
\hline
\end{tabular}


Indigenous Biography and Autobiography

\begin{tabular}{|c|c|c|c|}
\hline Author & Year & Author & Year \\
\hline Munro*M & 1996 & Mallett/F & 2001 \\
\hline Pilkington/F/ $\underline{\mathbf{B}}$ & 1996 & Pilbara Aboriginal Centre ${ }^{*} \mathbf{F}$ & 2001 \\
\hline Appo/F & 1997 & Riley/F/ B & 2001 \\
\hline $\mathrm{Bell} / \mathbf{F} / \underline{\mathbf{B}}$ & 1997 & Sykes/F & 2001 \\
\hline Chittick/M/ $\underline{\mathbf{B}}$ & 1997 & Taylor/M & 2001 \\
\hline Lovett-Gardiner/F & 1997 & Wright/F/ $\underline{\mathbf{B}}$ & 2001 \\
\hline Napanangka* $\mathrm{F}$ & 1997 & Bayet-Charlton/F & 2002 \\
\hline Sykes/F & 1997 & Brodie*F & 2002 \\
\hline Corrigan ${ }^{*} \mathrm{~F}$ & 1998 & Diwurruwurru-jaru* $\mathbf{M} \& \mathbf{F}$ & $\underline{2002}$ \\
\hline Fraser/ F & 1998 & Grant/M & 2002 \\
\hline Pryor* $\mathbf{M}$ & 1998 & Harrison ${ }^{*} \mathbf{M}$ & 2002 \\
\hline Sykes/F & 1998 & Lowe* M & 2002 \\
\hline Wilson/F & 1998 & Pilbara Aboriginal Centre/F & 2002 \\
\hline [n.a]/F & 1999 & Pilkington/F & 2002 \\
\hline Hegarty/F & 1999 & Purcell/F & 2002 \\
\hline J.K. ${ }^{*} \mathrm{~F}$ & 1999 & Rubuntja *M & 2002 \\
\hline Langford/F/ $\underline{\mathbf{B}}$ & 1999 & Russell/F/ B & 2002 \\
\hline Read/Coppin*M & 1999 & Smith *F & 2002 \\
\hline Walgar* M & 1999 & Aboriginal Community/M\&F & $\underline{2003}$ \\
\hline Williams* $\mathbf{F}$ & 1999 & Brown/F & 2003 \\
\hline Lenoy ${ }^{*} \mathbf{F}$ & $200(?)$ & Clarke* $\mathbf{M}$ & 2003 \\
\hline Barnes/F & 2000 & Collard/F & 2003 \\
\hline Bin-Sallik/F & 2000 & Crombie/F/ $\underline{\mathbf{B}}$ & 2003 \\
\hline Burgonye/F & 2000 & Freeman ${ }^{*} \mathbf{F}$ & 2003 \\
\hline Camfoo*M\&F & 2000 & Hegarty/F & 2003 \\
\hline Daley/M & 2000 & Kinnane/M & 2003 \\
\hline Dodd/M & 2000 & Peris * $\mathbf{F}$ & 2003 \\
\hline Kartinyeri/F & 2000 & Randall * M & 2003 \\
\hline Lalor* $\mathbf{M}$ & 2000 & Schilling/F & 2003 \\
\hline Lennon*F & 2000 & Beetson* $\mathbf{M}$ & 2004 \\
\hline McKellar ${ }^{*} \mathbf{F}$ & 2000 & Bent/F & 2004 \\
\hline Meehan/F & 2000 & Flick ${ }^{*} \mathbf{F}$ & 2004 \\
\hline Moriarty * M & 2000 & Hamilton*/F & 2004 \\
\hline Onus/M/ $\underline{\mathbf{B}}$ & 2000 & Marshall ${ }^{*} \mathbf{F}$ & 2004 \\
\hline Smith/F & 2000 & Moran* $\mathbf{M}$ & 2004 \\
\hline Sykes/F & 2000 & Muir/F & 2004 \\
\hline Chalarimeri/M & 2001 & Ngarta et al./F & 2004 \\
\hline Decker ${ }^{*} \mathbf{F}$ & 2001 & Schilling/F & 2004 \\
\hline Havnen/M\&F & 2001 & Tovey/M & 2004 \\
\hline Holt/M & 2001 & Wilson* $\mathbf{M}$ & 2004 \\
\hline Latham/M & 2001 & Wyllie/F/ $\underline{\mathbf{B}}$ & 2004 \\
\hline
\end{tabular}

Annotation to coding: $\mathbf{F}(\mathrm{emale})$ and $\mathbf{M}($ ale) refer to the gender of main author. If not indicated as $\underline{\mathbf{B}}$ (= biography), all items are autobiographies. Asterisk ${ }^{*}$ after name means 'as-told-to' story or editor/transcriber/assistant is named as additional author. All borderline cases (history/semi-autobiography) are italicised. Joint productions (anthologies) are underlined. Roberta Sykes is included. Mudrooroo has been omitted. 


\section{Bibliography of published Indigenous autobiographies}

Aboriginal Community Elders Service and Kate Harvey 2003, Aboriginal Elders' voices: Stories of the 'tide of history' - Victorian Indigenous Elders' life stories \& oral histories, Aboriginal Community Elders Service, Melbourne.

Appo, Josephine and Joyce Summers 1997, Wajehla Dubay: Women speakinAboriginal women's essays, stories and poems, Keeaira Press, Southport.

Barker, Jimmie and Janet Mathews 1977, The two worlds of Jimmy Barker: The life of an Australian Aboriginal 1900-1972, Aboriginal Studies Press, Canberra.

Barnes, Nancy 2000, Munyi's Daughter: A spirited brumby, Seaview Press, Henley Beach.

Bayet-Charlton, Fabienne 2002, Finding Ullagundahi Island, Allen \& Unwin, Crows Nest.

Beetson, Arthur et al. 2004, Big Artie. The autobiography, ABC, Sydney.

Bin-Sallik, Mary Ann (ed) 2000, Aboriginal women by degrees: Their stories of the journey towards academic achievement, University of Queensland Press, St Lucia.

Bohemia, Jack and William McGregor 1995, Nyibayarri: Kimberley tracker, Aboriginal Studies Press, Canberra.

Brodie, Veronica and Mary-Anne Gale 2002, My side of the bridge: The life story of Veronica Brodie, Wakefield Press, Kent Town.

Bropho, Robert 1980, Fringedweller, Alternative Publishing Co-operative, Sydney.

Brown, Eileen Kampakuta 2003, Anangu: An Anangu-Aboriginal love story-My young life. Nyiri Publications, Murray Bridge.

Burgoyne, Iris [Yumadoo Kochallalya] 2000, Mirning: We are the whales $-A$ Mirning-Kokatha woman recounts life before and after dispossession, Magabala Books, Broome.

Camfoo, Nellie and Gillian Cowlishaw 1995, Nellie Camfoo: Her story. Barunga Press, Katherine.

— and Gillian Cowlishaw 1995, Tex Camfoo: His story, Barunga Press, Katherine.

Camfoo, Tex, Nellie Camfoo and Gillian Cowlishaw 2000, Love against the Law: The autobiographies of Tex and Nellie Camfoo, Aboriginal Studies Press, Canberra.

Cawley, Evonne and Bud Collins 1975, Evonne!: On the move, Dutton, New York. Chalarimeri, Ambrose Mungala 2001, The man from the sunrise side, Magabala Books, Broome. 
Indigenous Biography and Autobiography

Clare, Monica 1978, Karobran: The story of an Aboriginal girl, Alternative Publishing Cooperative, Chippendale.

Clarke, Banjo and Camilla Chance 2003, Wisdom Man, Viking, Camberwell.

Clements, Theresa c.1954, From Old Maloga: The memoirs of an Aboriginal woman, Fraser \& Morphet, Prahran.

Cohen, Bill 1987, To My Delight: The Autobiography of Bill Cohen, a grandson of the Gumbangarri, Aboriginal Studies Press, Canberra.

Cohen, Patsy and Margaret Somerville 1990, Ingelba and the five black matriarchs, Allen \& Unwin, Sydney.

Collard, Dot and Beryl Hackner 2003, Busted Out Laughing: Dot Collard's Story as told to Beryl Hackne, Magabala Books, Broome.

Corrigan, Florence and Loreen Breahut 1998, Miles of post and wire, Magabala Books, Broome.

Crawford, Evelyn 1993, Over my tracks, Penguin, Ringwood.

Daley, Laurie and David Middleton 2000, Laurie: Always a winner, HarperCollins Publishers, Pymble.

Davis, Jack 1991, A boy's life, Magabala Books, Broome.

Decker, Diane and Marjorie Woodrow 2001, Long time coming home: As recalled by Marjorie Woodrow, Marjorie Woodrow, Lake Haven.

Dhoulagarle, Koorie [Roy Simon] 1979, There's more to life, Alternative Publishing Co-operative, Chippendale.

Diwurruwurru-Jaru Aboriginal Corporation and Lana Quall 2002, So far from home: Oral histories of the Stolen Generations, Diwurruwurru-Jaru Aboriginal Corp., Katherine.

Dodd, Bill 1992, Broken dreams, University of Queensland Press, St Lucia.

Dodd, Martin 2000, They liked me, the horses, straightaway, Ginninderra Press, Charnwood.

Edmund, Mabel 1992, No regrets, University of Queensland Press, St Lucia.

Flick, Isabel and Heather Goodall 2004, Isabel Flick: The life story of a remarkable Aboriginal leader, Allen \& Unwin, Crows Nest.

Fraser, Rosalie 1998, Shadow child: A memoir of the Stolen Generation, Hale \& Iremonger, Sydney.

Freeman, Cathy and Scott Gullan 2003, Cathy: Her own story, Penguin, Camberwell.

Gaffney, Ellie 1989, Somebody now: The autobiography of Ellie Gaffney, a woman of Torres Strait, Aboriginal Studies Press, Canberra. 
Gibbs, Jack 1995, Son of Jimmy, Historical Society of the Northern Territory, Darwin.

Grant, Stan 2002, The tears of strangers: A memoir, HarperCollins, Pymble.

Hamilton, Fiona et al. 2004, Aboriginal women's heritage: Brungle \& Tumut, Department of Environment and Conservation, Hurstville.

Hamilton, Jean, Joan McKenzie and Katherine McKenzie 1989, Just Lovely, J. McKenzie, Coonamble.

Harney [Yidumduma], Bill and Jan Wositzky 1996, Born under the paperbark tree: A man's life, ABC, Sydney.

Harrison, Shorty 1994, All hearts bleed the same: Reflections, recollections and memories, an autobiography, Bill Harrison, Nowra.

Harrison, Harald John, Jack Miller and Michele Miller 2002, Living in two cultures: Memories of Harold Harrison, Bournda Environmental Education Centre, Kalaru.

Havnen, Peg and Leonie Norrington 2001, Under the mango tree: Oral histories with Indigenous people from the Top End, NT Writers' Centre Inc., Darwin.

Hegarty, Ruth 1999, Is that you Ruthie?, University of Queensland Press, St Lucia.

_2003, Bittersweet journey, University of Queensland Press, St Lucia.

Holt, Albert 2001, Forcibly removed, Magabala Books, Broome.

J.K., Janine Clancy and Sisters Inside 1999, My prison experience, Sisters Inside, South Brisbane.

Jangala, Abie et al. 1977, Stories from Lajamanu, NT Department of Education, Darwin.

Kartinyeri, Doris 2000, Kick the tin, Spinifex Press, North Melbourne.

Kennedy, Marnie 1985, Born a half-caste, Aboriginal Studies Press, Canberra.

King, Wayne 1996, Black hours, Angus \& Robertson, Sydney.

Kinnane, Stephen 2003, Shadow lines, Fremantle Arts Centre Press, Fremantle.

Lalor, Myles and Jeremy Beckett 2000, Wherever I go: Myles Lalor's 'oral history', Melbourne University Press, Carlton.

Lamilami, Lazarus and JM Bolton 1974, Lamilami speaks: The cry went up, a story of the people of Goulburn Islands, North Australia, Ure Smith, Sydney.

Langford, Ruby 1988, Don't take your love to town, Penguin, Ringwood.

— 1992, Real deadly, Angus \& Robertson, Pymble.

— 1994, My Bundjalung people, University of Queensland Press, St Lucia. 
Indigenous Biography and Autobiography

Latham, George 2001, Copper Wire George, Yamaji Language Centre, Geraldton.

Lennon, Jessie et al. 1996, And I Always Been Moving! The early life of Jessie Lennon, Jessie Lennon and Michele Madigan, Coober Pedy.

Lennon, Jessie and Michele Madigan 2000, I'm the one that know this country: The story of Jessie Lennon and Coober Pedy, Aboriginal Studies Press, Canberra.

Lenoy, Norma, Angela Zammatora et al. 200[?], Norma's story, Creative Support, Cairns.

Lester, Yami 1993, Yami: The autobiography of Yami Lester, Institute for Aboriginal Development, Alice Springs.

Lovett-Gardiner, Iris 1997, Lady of the lake: Aunty Iris's story, Koorie Heritage Trust, Melbourne.

Lowah, Thomas and Ray Crooke 1988, Eded mer (my life), Rams Skull Press, Kuranda.

Lowe, Robert and Framlingham Mission 2002, The Mish, University of Queensland Press, St Lucia.

McAdam, Charlie and Elizabeth Tragenza 1995, Boundary lines: A family's story of winning against the odds, McPhee Gribble, Ringwood.

McDonald, Connie [Nungulla] and Jill Finnane 1996, When you grow up, Magabala Books, Broome.

McGinness, Joe 1991, Son of Alyandabu: My fight for Aboriginal rights, University of Queensland Press, St Lucia.

McKellar, Hazel 2000, Woman from nowhere: Hazel McKellar's story [as told to Kerry McCallum], Magabala Books, Broome.

McKenna, Clancy and Kingsley Palmer 1978, Somewhere between black and white: The story of an Aboriginal Australian, Macmillan, South Melbourne.

McKenzie, Janet 1983a, Ebenezer, New Creation Publications, Blackwood.

— 1983b, Fingal tiger, New Creation Publications, Blackwood.

McKenzie, Ruth 1989, Molly Lennon's story: That's how it was [as told to Jen Gibson], Aboriginal Heritage Branch, Adelaide.

McPhee, Jack and Patricia Konigsberg 1994, Bee Hill River Man: Kandulangu-bidi. Memories of Jack McPhee, Magabala Books, Broome.

Mallett, Molly 2001, My past - their future: Stories from Cape Barren Island, Blubber Head Press, Sandy Bay.

Marika, Wandjuk and Jennifer Isaacs 1995, Wandjuk Marika: Life story, University of Queensland Press, St Lucia. 
Marshall, Lucy and Colleen Hattersley 2004, Reflections of a Kimberley woman, Madjulla Inc., Broome.

Medcraft, Rosalie and Valda Gee 1995, The sausage tree, University of Queensland Press, St Lucia.

Meehan, Donna 2000, It is no secret, Random House, Milsons Point.

Mirritji, Jack et al. 1978, My people's life: An Aboriginal's own story, Milingimbi Literature Centre, Milingimbi.

Moran, Charles Harold and Glennys Moran 2004, Talk softly, listen well: Profile of Bundjalung elder, Charles Moran, Southern Cross University Press, Lismore.

Morgan, Eileen 1994, The calling of the spirits, Aboriginal Studies Press, Canberra.

Morgan, Sally 1987, My place, Fremantle Arts Centre Press, Fremantle.

Morgan, Sally and Barbara Ker Wilson 1990a, Sally's story. Fremantle Arts Centre Press, Fremantle.

1990b, Mother and daughter: The story of Daisy and Gladys Corunna, Fremantle Arts Centre Press, Fremantle.

Moriarty, John and Evan McHugh 2000, Saltwater fella, Viking, Ringwood.

Mumshirl and Bobbi Sykes 1981, MumShirl: An autobiography with the assistance of Bobbi Sykes, Heinemann, Richmond.

Muir, Hilda Jarman 2004, Very big journey: My life as I remember it, Aboriginal Studies Press, Canberra.

Munro, Morndi and Mary-Anne Jebb 1996, Emerarra: A Man of Merarra, Magabala Books, Broome.

n.a. 1999, Holding Up the Sky. Aboriginal women speak, Magabala Books, Broome.

Nannup, Alice, Lauren Marsh and Stephen Kinnane 1992, When the pelican laughed, Fremantle Arts Centre Press, Fremantle.

Napanangka, Tjemma Freda, Pamela Lofts and Sonja Peter 1997, Yarrtji: Six Women's Stories from the Great Sandy Desert, Aboriginal Studies Press, Canberra.

Neidjie, Bill, Stephen Davis and Allan Fox 1985, Kakadu Man: Bill Neidjie, Mybrood, Queanbeyan.

Ngabidj, Grant and Bruce Shaw 1981, My country of the pelican dreaming: The life of an Australian Aborigine of the Gadjerong, Grant Ngabidj, 1904-1977 - as told to Bruce Shaw, Australian Institute of Aboriginal Studies, Canberra. 
Indigenous Biography and Autobiography

Ngarta, Bent et al. 2004, Two sisters: Ngarta \& Jukuna, Fremantle Arts Centre Press, Fremantle.

Nungurrayi, Lumu and Jordan Crugnale 1995, Footprints across our Land: Short stories by senior desert women, Magabala Books, Broome.

Noonuccal, Oodgeroo [Kath Walker] 1972, Stradbroke Dreamtime, Angus \& Robertson, Sydney.

Pederson, Howard and Banjo Woorrnmurra 1995, Jandamarra and the Bunuba resistance, Magabala Books, Broome.

Peris, Nova and Ian Heads 2003, Nova: My story: The autobiography of Nova Peris, ABC, Sydney.

Perkins, Charles 1975, A bastard like me, Ure Smith, Sydney.

Pilbara Aboriginal Language Centre et al. 2002, Thalanjyi gujurunyjarri: Jarburda Thalanyjigu guliyarriyarra ngarrarigu (Thalanyi Stories: thinking about Thalanyji country), Wangka Maya Pilbara Aboriginal Language Centre, South Hedland.

Pilbara Aboriginal Language centre and Rose Murray 2001, Wumun turi: Pilbara Aboriginal women's stories, Wangka Maya Pilbara Language Centre, Port Headland.

Pilkington, Doris [Nugi Garimara] 1991, Caprice: A stockman's daughter,

University of Queensland Press, St Lucia.

2002, Under the Wintamarra tree, University of Queensland Press, St Lucia.

Pring, Adele (ed) 1990, Women of the Centre, Pascoe, Apollo Bay.

Pryor, Boori and Meme McDonald 1998, Maybe tomorrow, Penguin, Ringwood.

Purcell, Leah (ed) 2002, Black chicks talking, Hodder Headline, Sydney.

Raggett, Obed and Bill Marshall-Stoneking 1980, Stories of Obed Raggett, Alternative Publishing Co-operative, Sydney.

Randall, Bob and Paul Newbury 2003, Songman: The story of an Aboriginal Elder of Uluru, ABC, Sydney

Read, Jolly and Peter Coppin 1999, Kangkushot: The life of Nyamal Lawman Peter Coppin, Aboriginal Studies Press, Canberra.

Rose, Lionel Edmund 1969, Lionel Rose: Australian — The life story of a champion - As told to Rod Humphries, Angus \& Robertson, Sydney.

Roughsey, Dick [Goobalathaldin] 1971, Moon and rainbow: The autobiography of an Aboriginal, Reed, Sydney.

Roughsey, Elsie [Labumore] and Paul Memmot 1984, An Aboriginal mother tells of the old and the new, McPhee Gribble/Penguin, Fitzroy/Ringwood. 
Rubuntja, Wenten, Tim Rowse and Jenny Green 2002, The town grew up dancing: The life and art of Wenten Rubuntja, Jukurrpa Books, Alice Springs.

Saunders, Keith 1992, Learning the ropes, Aboriginal Studies Press, Canberra.

Schilling, Kath et al. 2003, Aboriginal women's heritage: Nambucca, NSW National Parks and Wildlife Service, Hurstville.

—2004, Aboriginal women's heritage: Nowra, NSW National Parks and Wildlife Service, Hurstville.

Simon, Ella 1978, Through my eyes: Autobiography of a part Aborigine, Rigby, Adelaide.

Sing, (Sabu) Peter and Pearl Ogden 1992, From humpy to homestead: The biography of Sabu, Pearl Ogden, Darwin.

Smith, Alice [Bilari], Anna Vitenberg and Loreen Brehaut 2002, Under a Bilari tree I born: A story of Alice Bilari Smith, Fremantle Arts Centre Press, Fremantle.

Smith, Ollie and Diana Plater 2000, Raging partners. Two worlds, one friendship, Magabala Books, Broome.

Somerville, Margaret, Marie Dundas et al. 1994, The sun dancin': People and place in Coonabarabran, Aboriginal Studies Press, Canberra.

Sullivan, Jack and Bruce Shaw 1983, Banggaiyerri: The story of Jack Sullivan as told to Bruce Shaw, AIAS, Canberra.

Sykes, Roberta (ed) 1993, Murawina: Australian women of high achievement, Doubleday, Sydney.

— 1997, Snake cradle, Allen \& Unwin, Crows Nest.

_ 1998, Snake dancing, Allen \& Unwin, Crows Nest.

-2000, Snake circle, Allen \& Unwin, Crows Nest.

_2001, Snake dreaming: Autobiography of a black woman, Allen \& Unwin, Crows Nest.

Tatz, Colin and Keith McConnochie (eds) 1975, Black viewpoints. The Aboriginal experience. Australia and New Zealand Book Co., Sydney.

Taylor, Alf 2001, Long time now: Stories of the Dreamtime, the here and now, Magabala Books, Broome.

Thaiday, Willie 1981, Under the act, N.Q. Black Publishing, Townsville.

Thancoupie and Ulli Beier 1988, I keep my head above my shoulders, and I try to keep him strong and high, Long Water.

Thomson, Judy 1989, Reaching back, Queensland Aboriginal people recall early days at Yarrabah Mission, Aboriginal Studies Press, Canberra. 
Indigenous Biography and Autobiography

Tovey, Noel 2004, Little black bastard: A story of survival, Hodder Headline, Sydney.

Tucker, Margaret and Kim Beazley 1977, If everyone cared: Autobiography, Ure Smith, Sydney.

Unaipon, David 1951, My life story, Aborigines Friends Association, Melbourne.

Vaarzon-Morel, Petronella, Molly Nungarrayi et al. 1995, Warlpiri karnta karnta-kurlangu yimi (Warlpiri women's voices: our lives our history), IAD Press, Alice Springs.

Walgar, Monty and Cloud Shabalah 1999, Jinangga: On my tracks, Magabala Books, Broome.

Walker, Della and Tina Coutts 1989, Me and you: The life story of Della Walker, Aboriginal Studies Press, Canberra.

Ward, Glenyse 1987, Wandering Girl, Magabala Books, Broome.

_ 1991, Unna You Fullas, Magabala Books, Broome.

White, Isobel and Betty Meehan 1985, Fighters and singers: The lives of some Australian Aboriginal women, Allen \& Unwin, Sydney.

West, Ida 1984, Pride Against prejudice: Reminiscences of a Tasmanian Aborigine, Aboriginal Studies Press, Canberra.

Williams, Magdalene and Pat Torres 1999, Ngay janijirr ngank: This is my word, Magabala Books, Broome.

Wilson, Dulcie 1998, The cost of crossing bridges, Small Poppies Publishing, Mitcham.

Wilson, Garnet Ian and Anne Bartlett 2004, The chairman: The story of Garnett Ian Wilson, Australian Scholarly Publishing, Melbourne.

Woodrow, Marjorie 1990, One of the Lost Generation, Marjorie Woodrow, Narromine.

\section{Bibliography of published Indigenous biographies}

Anderson, Barbara 1994, Think before you judge, Barbara Anderson, Frankston. Bell, Jeanie 1997, Talking About Celia: Community and family memories of Celia Smith, University of Queensland Press, St Lucia.

Chesson, Keith 1988, Jack Davis: A life-story, Dent, Melbourne.

Chittick, Lee and Terry Fox 1997, Travelling with Percy: A South Coast journey, Aboriginal Studies Press, Canberra.

Chryssides, Helen 1993, Local heroes, Collins Dove, North Blackburn. 
Coe, Mary and Isabell Coe 1986, Windradyne: A Wiradjuri Koorie, Blackbooks, Glebe.

Crombie, Eileen [Unkari] 2003, He was a South Australian film star: My life with Billy Pepper, Nyiri Publications, Murray Bridge.

Edmund, Mabel 1996, Hello, Johnny!: Stories of my Aboriginal and South Sea Islander family. Central Queensland University Press, Rockhampton.

Goolagong Cawley, Evonne and Phil Jarrat 1993, Home!: The Evonne Goolagong story. Simon \& Schuster, East Roseville.

Huggins, Rita and Jackie Huggins 1994, Auntie Rita, Aboriginal Studies Press, Canberra.

Langford, Ginibi 1999, Haunted by the past, Allen \& Unwin, St Leonards.

Mabo, Koiki Edward and Noel Loos 1996, Edward Koiki Mabo: His life and struggle for land rights, University of Queensland Press, St Lucia.

Moran, Rod 1995, Icon of the north: The legend of Tom Gray, Access Press, Northbridge.

Morgan, Sally 1989, Wanamurraganya: The story of Jack McPhee, Fremantle Arts Centre Press, Fremantle.

Morgan, Sally and Barbara Ker Wilson 1990c, Arthur Corunna's story, Fremantle Arts Centre Press, Fremantle.

Onus, Lin, Michael Eather, Margo Neale et al. 2000, Urban dingo: The art and life of Lin Onus, 1948-1996, Craftsman House in association with the Queensland Art Gallery, South Brisbane.

Pepper, Phillip 1980, You are what you make yourself to be: The story of a Victorian Aboriginal family 1842-1980, Hyland House, Melbourne.

Pilkington, Doris [Nugi Garimara] 1996, Follow the rabbit-proof fence, University of Queensland Press, St Lucia.

Prior, Renarta 1993, Straight from the Yudaman's mouth: The life story of Peter Prior before, during and after Robert Curry days, never told before, Department of History and Politics, James Cook University, Townsville.

Riley, Linette and Riley, Samantha 2001, The life of Riley, Random House, Milsons Point.

Rosser, Bill 1985, Dreamtime nightmares: Biographies of Aborigines under the Queensland Aborigines Act, Australian Institute of Aboriginal Studies, Canberra.

Russell, Lynette 2002, A little bird told me: Family secrets, necessary lies, Allen \& Unwin, Crows Nest. 
van den Berg, Rosemary 1994, No options, no choice! The Moore River experience: My father, Thomas Corbett, an Aboriginal half-caste, Magabala Books, Broome.

Willmot, Eric Paul 1987, Pemulwuy, the rainbow warrior, Weldons, McMahons Point.

Wilson, Graham 1989, Pilbara bushman: The life experience of W. Dunn, Hesperian Press, Victoria Park.

Wood, Roma 1995, The young soldier from the Goldfields, Hesperian Press, Carlisle.

Wright, Edie 2001, Full circle: From mission to community - A family story, Fremantle Arts Centre Press, Fremantle.

Wyllie, Diana 2004, Dolly Dalrymple, Diana Wyllie, Childers.

\section{'Bulman oral history series'}

13 books published by Barunga Press, Katherine, 1995; co-authored by Gillian Cowlishaw.

\section{References}

\section{Unpublished sources}

Haag, Oliver 2006, 'Histories of Survival. Australian Indigenous Women's Auto/Biographies, Past and Present', Thesis (Diplomarbeit), University of Vienna, Vienna.

Watson, Christine 2001, "'My own eyes witness": Australian Aboriginal women's autobiographical narratives', PhD Thesis, University of Queensland, St Lucia.

Westphalen, Linda 2002, 'Deadly Lives: Palimpsests in Aboriginal Women's Life-Histories', PhD Thesis, Flinders University of South Australia, Adelaide.

\section{Translated autobiographies (select)}

Langford, Ruby 2000, Bonalbon Musta Ruby, Kääntöpiiri, Päivi Paapanen. Morgan, Sally 1991, Ich hörte den Vogel rufen. Roman, Orlanda, Berlin.

_2002, Wanamurraganya. Die Geschichte von Jack McPhee, Unionsverlag, Zürich.

Pilkington, Doris [Nugi Garimara] 2003, Long Walk Home: Die wahre Geschichte einer Flucht quer durch die Wüste Australiens, Rowohlt, Reinbek. 


\section{Published sources}

Anderson, Ian 2000, 'Post-colonial Dreaming at the end of the whitefella's 'millennium', in The Oxford companion to Aboriginal art and culture, Sylvia Kleinert and Margo Neale (eds), Oxford University Press, Melbourne: 427-437.

Anderson, Linda 2001, Autobiography, Routledge, London.

Angrosino, Michael 1989, Documents of interaction: Biography, autobiography, and life history in social science perspective, University of Florida Press, Gainesville.

Attwood, Bain and Fiona Magowan (eds) 2001, Telling stories: Indigenous history and memory in Australia and New Zealand, Bridget William Books, Wellington.

Blackburn, Regina 1980, 'In search of the black female self: African-American women's autobiographies and ethnicity', in Women's autobiography: Essays in criticism, Estelle Jelinek (ed), Indiana University Press, Bloomington, London: 133-148.

Brettel, Caroline 1997, 'Blurred Genres and Blended Voices: Life History, Biography, Autobiography, and the Auto/Ethnography of Women's Lives' in Auto/ethnography: Rewriting the self and the social, Deborah Reed-Danahay (ed), Berg, Oxford, London: 223-246.

Brewster, Anne 1996, Reading Aboriginal women's autobiography, Sydney University Press in association with Oxford University Press, South Melbourne.

Cooper, Judi et al. 2000, 'To tell my story. A study of practising professional Indigenous writers of Australia', Research report, Australia Council for the Arts, Sydney.

Duthil, Fanny 2006, Histoire de femmes Aborigènes, Presses Universitaires des France, Paris.

Ferrier, Carole 1992 [1988], 'Aboriginal women's narratives' in Gender, politics and fiction: Twentieth century Australian women's novels, Carole Ferrier (ed), University of Queensland Press, St Lucia: 200-218.

Geiger, Susan 1986, 'Women's life histories: method and content', Signs 11(2): 334-351.

Grossman, Michele (ed) 2003, Blacklines: Contemporary critical writing by Indigenous Australians, Melbourne University Press, Carlton.

Gusdorf, Georges 1980, 'Conditions and Limits of Autobiography', in Autobiography: Essays theoretical and critical, James Olney (ed), Princeton University Press, Princeton: 28-48. 
Hamilton, Paula 1990, 'Inventing the self. Oral history as autobiography', Hecate 16(1/2): 128-133.

Heiss, Anita 2003, Dhuuluu-Yala: To talk straight - Publishing Indigenous literature, Aboriginal Studies Press, Canberra.

Hetherington, Isabella 1929, Aboriginal queen of sacred song: Her life story, Saxton \& Buckie, Melbourne.

Jones, Jennifer 2003, 'Oodgeroo and her editors. The production of Stradbroke Dreamtime', Journal of Australian Studies 76: 47-56.

Koolmatrie, Wanda 1994, My own sweet time, Magabala Books, Broome.

Korporaal, Glenda 1990, Project Octopus: The publishing and distribution ownership structure in the book industry, in Australia and internationallyImplications of the changes for Australian authors, Australian Society of Authors, Redfern.

Langton, Marcia 1993, 'Well, I heard it on the radio and I saw it on the television...': An essay for the Australian Film Commission on the politics and aesthetics of filmmaking by and about Aboriginal people and things, Australian Film Commission, Woolloomooloo.

Lockwood, Douglas 1962, I, the Aboriginal, Rigby, Adelaide.

McCooey, David 1996, Artful histories: Modern Australian autobiography, Cambridge University Press, Melbourne.

_2006, 'Going public: a decade of Australian autobiography', Australian Book Review 281, May 2006: 25-31.

McDonell, Margaret 2004, 'Protocols, political correctness and discomfort zones: Indigenous life writing and non-Indigenous editing', Hecate 30(1): 83-95.

Moreton-Robinson, Aileen 2002 [2000], Talkin' up to the white woman. Indigenous women and feminism, University of Queensland Press, St Lucia.

Mudrooroo 1990, Writing from the fringe: A study of modern Aboriginal literature, Hyland House, Melbourne.

Olijnyk Longley, Kateryna 1992, 'Autobiographical storytelling by Australian Aboriginal Women', in De/Colonizing the Subject: The politics of gender in women's autobiography, Sidonie Smith and Julia Watson (eds), University of Minnesota Press, Minneapolis: 370-384.

Phillips, Sandra 1997, 'Aboriginal women's writing today', Hecate's Australian Women's Book Review 9: 40-42. 
Rowse, Tim 2004, 'Indigenous autobiography in Australia and the United States', Australian Humanities Review August-October, Accessed 25 June 2007, http://www.lib.latrobe.edu.au/AHR/archive/Issue-August-2004/rowse.html/

Rühl, Christiane 1997, Die autobiographische Literatur australischer Aborigines-Frauen: Eine ethnologische Studie, Lang, Frankfurt.

Schürmann-Zeggel, Heinz 1997, Black Australian literature: A bibliography of fiction, poetry, drama, oral traditions and non-fiction, including critical commentary, 1900-1991, Lang, Bern.

1999, Life Writing: Literarische Identitätskonstruktionen in schwarzaustralischen Autobiographien und Lebensgeschichten, Lang, Bern.

Shaw, Bruce 1982-1982, 'Writing Aboriginal history for the East Kimberley: methodology and themes', Oral History Association of Australia Journal 5: 75-83.

Shoemaker, Adam 1995, 'Does paper stay put? The politics of Indigenous literature in Canada and Australia', in Speaking positions: Aboriginality, gender and ethnicity in Australian cultural studies, Penny van Toorn and David English (eds), Victoria University of Technology, Melbourne: 73-89.

Thonemann, Harold Eric 1949, Tell the white man: The life story of an Aboriginal Lubra, Collins, London.

Zierott, Nadja 2005, Aboriginal women's narratives: Reclaiming identities, Lit Verlag, Münster.

\section{ENDNOTES}

${ }^{1}$ I thank Peter Read for his feedback on the earlier version of this article. I am also grateful to Frances Peters-Little, Jackie Huggins, and Maria Preethi Srinivasan for expanding my thinking on Indigenous autobiography.

2 This paper is based on a fuller empirical documentation, see Haag 2006. In stark contrast to articles and theses, little monographic literature addresses Indigenous (Australian) autobiography. Brewster 1996 is hitherto the only Australian-originated book entirely devoted to the topic. Other books, such as McCooey 1996, Attwood and Magowan 2001, and Grossman 2003 deal only partially with published Indigenous autobiographies. See Rowse 2004 for an assessment of this literature.

3 Production-Authorship refers to the relation between single- and co-authored items.

${ }^{4}$ This study uses a plenitude of interviews conducted with Indigenous writers. See Heiss 2003: 26.

${ }^{5}$ The current definition of an Indigenous person is threefold: descent, self-identification, and community acceptance. See Langton 1993: 29.

${ }^{6}$ This includes Koolmatrie/Carmen and Mudrooroo, but not Sykes. Koolmatrie 1994 is a forged Indigenous woman's autobiography. Heiss 2003: 8-9 does not include Sykes' and Mudrooroo's books in her bibliography. I include Sykes' with a special annotation because the debates surrounding Sykes are not clear-cut.

7 Hetherington 1929; Thonemann 1949; Lockwood 1962.

${ }^{8}$ Due to length restrictions, I cannot reference all these cases. For a fuller survey, see Haag 2006: 14-15. A few examples should suffice. For fiction, see Ferrier 1992; for lifestory, see Phillips 1997: 40.

9 There is no consistent definition and usage of these genres in international scholarship. Often, life story and oral history are understood as an account of select life experiences. See Brettel 1997: 224, 227. 
Hamilton 1990, however, regards oral history as a form of autobiography. Life history in turn is often seen as an 'as told to story'. See Angrosino 1989: 3; Geiger 1986: 336. For a discussion of these terms in the Australian context, see Shaw 1982-1983.

10 See Rowse 2004; Brewster 1996; Watson 2001: 12-17.

11 See Moreton-Robinson 2002: 1, 16.

12 See Westphalen 2002: 12-13, 22, 29-31, 73, 78-88, 105, 227-228.

13 See Mudrooroo 1990: 14-15, 149, 158-161, 163.

14 See Gusdorf 1980: 29-30.

15 See Anderson 2001: 86; Blackburn 1980: 133-134.

16 These are 13 booklets (between seven and 19 pages in length), all published in 1995 by Barunga Press. They are transcribed and co-authored by Cowlishaw. Including them would falsify the statistics due to their arithmetic extremes (that is, their shortness and the circumstance of their having been published by the same press within a group project).

17 Most bibliographies are unpublished, fragmentary, or dated. Here, I can reference only a few: Heiss 2003: 222-228; Watson 2001: 242-250; Schürmann-Zeggel 1997: 131-155.

18 Unless otherwise indicated, the findings are taken from the extended bibliography.

19 This survey is based upon the responses of 215 Indigenous writers. It shows women dominating most genres, including family history and academic writings. See Cooper et al. 2000: 3, 12, 42.

20 For this policy, see Anderson 2000: 431-432. Rowse 2004 discusses the usefulness of a periodisation of Indigenous autobiographies along the policies towards Indigenous peoples.

21 See Jones 2003; McDonell 2004.

22 See Morgan 1987; Nannup et al. 1992; Huggins and Huggins 1994.

23 See Brewster 1996: 7; Olijnyk Longley 1992: 376-377.

24 See Shoemaker 1995: 75.

25 This is the case not only with Indigenous autobiography but also with Australian non-fictional writing in general that has amassed throughout the last decades. Consequently, Indigenous autobiography should not be treated as an isolated phenomenon. See McCooey 2006: 26; Korporaal 1990: 12-13.

${ }^{26}$ Statistically, the third of the three major Indigenous presses, IAD Press, including its imprint Jukurrpa Books, has not been decisive as regards the autobiographical genre. For a good overview of publishers, see Heiss 2003: 51-65.

27 Morgan 1987.

28 See Rühl 1997; Schürmann-Zeggel 1999; Zierott 2005; Duthil 2006.

29 See Morgan 1991.

30 See Morgan 2002.

31 See Langford 2000.

32 See Pilkington 2003. 